\title{
BAX Contributes to Apoptotic-Like Death Following Neonatal Hypoxia-Ischemia: Evidence for Distinct Apoptosis Pathways
}

\author{
Margaret E. Gibson ${ }^{1}$, Byung Hee Han ${ }^{1}$, Junjeong Choi ${ }^{1}$, C. Michael Knudson ${ }^{2}$, Stanley J. Korsmeyer ${ }^{3}$, \\ Maia Parsadanian', David M. Holtzman ${ }^{1,4,5}$ \\ ${ }^{1}$ Departments of Neurology, ${ }^{4}$ Molecular Biology and Pharmacology, and the ${ }^{5}$ Center for the Study of Nervous \\ System Injury, Washington University School of Medicine, St. Louis, MO \\ ${ }^{2}$ Dept. Pathology, University of Iowa, Iowa City, Iowa \\ ${ }^{3}$ Department of Pathology and Medicine, Harvard Medical School, Dana-Farber Cancer Institute, Boston, MA \\ Accepted August 10, 2001
}

\begin{abstract}
Background: Hypoxic-ischemic (H-I) injury to the neonatal brain has been shown to result in rapid cell death with features of acute excitotoxicity/necrosis as well as prominent delayed cell death with features of apoptosis such as marked caspase- 3 activation. BAX, a pro-apoptotic molecule, has been shown to be required for apoptotic neuronal cell death during normal development but the contribution of endogenous BAX in cell death pathways following $\mathrm{H}-\mathrm{I}$ injury to the developing or adult brain has not been studied.

Materials and Methods: $B a x+/+,+/-$, and $-/-$ mice at post-natal day 7 were subjected to unilateral carotid ligation followed by exposure to 45 minutes of $8 \%$ oxygen. At different timepoints following $\mathrm{H}-\mathrm{I}$, brain tissue was studied by conventional histology, immunohistochemistry, immunofluorescence, Western blotting, and enzymatic assay to determine the extent and type of cell injury as well as the amount of caspase activation.
\end{abstract}

Results: We found that bax $-/-$ mice had significantly less $(38 \%)$ hippocampal tissue loss than mice expressing bax. Some of the remaining cell death in bax $-/-$ mice, however, still had features of apoptosis including evidence of nuclear shrinkage and caspase-3 activation. Though bax $-/-$ mice had significantly decreased caspase- 3 activation as compared to bax expressing mice following $\mathrm{H}-\mathrm{I}$, the density of cells with activated caspase- 8 in the CA3 region of the hippocampus did not differ between bax $+/-$ and bax $-/-$ mice.

Conclusions: These findings demonstrate that endogenous BAX plays a role in regulating cell death in the central nervous system (CNS) following neonatal H-I, a model of cerebral palsy. In addition, while BAX appears to modulate the caspase- 3 activation following neonatal $\mathrm{H}-\mathrm{I}$, caspase-8 which is linked to death receptor activation, may contribute to apoptotic-like neuronal death in a BAX-independent manner.

\section{Introduction}

Apoptosis or programmed cell death is an important component of nervous system development $(1,2)$. Cell death, which has features of apoptosis, is also prominent in the developing brain following hypoxiaischemia $(\mathrm{H}-\mathrm{I})$ (3-10). Many checkpoints of regulation exist in this pathway (reviewed in $(11,12)$ ), including the $\mathrm{Bcl}-2$ family checkpoint. Interactions between different BCL-2 family members have the potential to regulate whether a cell lives or dies (reviewed in (13)). Anti-apoptotic family members, such as BCL-2 and BCL- $\mathrm{X}_{\mathrm{L}}$, can heterodimerize through homologous domains with pro-apoptotic members, such as BAX (13-15). If a balance does not exist and protective members of the BCL-2 family are in excess, cells can be protected. However, when BAX or BAX homologues are in excess,

Address correspondence and reprint requests to David M. Holtzman, MD, Washington University School of Medicine, Dept. of Neurology, 660 S. Euclid Ave., Box 8111, St. Louis, MO 63110, Phone: 314-362-9872, fax: 314-362-2826,

e-mail: holtzman@neuro.wustl.edu homodimers can dominate and cells are more susceptible to apoptosis (14).

Studies have shown that endogenous BAX is important in programmed neuronal cell death. In bax $-/-$ mice, sympathetic, peripheral nervous system (PNS), motor, and cerebellar granule neurons are all dramatically protected from apoptosis both in vitro and in vivo (15-19). Although BAX plays an important role under these circumstances and in these cells, few studies have examined a role for endogenous BAX in the cell death which occurs in the normal or injured CNS. Recently, it was shown that BAX regulates apoptosis following ionizing radiation to the CNS (20) and that pathological cell death seen in cerebellar granule neurons but not in Purkinje cells in Lurcher mice is BAX dependent (19). Whether endogenous BAX plays a role following other types of injury to the developing or adult CNS such as H-I has not been defined.

$\mathrm{H}$-I encephalopathy in the prenatal and perinatal period is a major cause of morbidity and mortality and can result in cerebral palsy $(21,22)$. Models of $\mathrm{H}-\mathrm{I}$ in neonatal animals have been shown to mimic 
many of the pathological and cognitive abnormalities that are seen in children who have sustained a H-I insult (21-23). The Levine model of $\mathrm{H}-\mathrm{I}$ includes unilateral carotid artery ligation followed by exposure to hypoxia $(24,25)$. In this model, injury occurs in the hemisphere ipsi- but not contralateral to the ligation, and there are prominent features of both apoptosis as well as necrosis (8-10,26-28). Apoptotic/caspasedependent injury appears to contribute to as much as $50 \%$ of the tissue loss following neonatal H-I $(9,29)$. In recent studies, we have utilized this model in different transgenic and knockout mice to determine the role of specific genes in H-I induced brain damage (30). We find that nNOS and clusterin exacerbates the injury $(28,31)$ while overexpression of $B C L-X_{L}$ is protective (29). We implemented this model in bax $-/-$ mice to study the role of BAX in apoptotic-like death following neonatal H-I.

\section{Materials and Methods \\ Animals and Surgical Procedures}

Bax $+/-$ male mice and bax $-/-$ female mice on a C57BL/6 background were produced as described (32). Domains $\mathrm{BH} 1$ and $\mathrm{BH} 2$ were deleted rendering the protein non-functional by a BAX targeting vector, which substituted PGK-Neo for exons 2 through 5. The disrupted BAX allele was transferred through the germ line. All mice were housed under a 12:12 hr light:dark cycle, with food and water available during the duration of the study. The neonatal H-I brain injury followed the Levine procedure $(21,24,25$, $30,33,34)$. At postnatal day 7 (P7), pups were anesthetized with $2.5 \%$ halothane (balance room air), and the left common carotid artery was surgically exposed and permanently ligated. The incision was sutured and the pups were returned to the mother for a 2 hour recovery and feeding period. Pups were placed in individual containers $\left(37^{\circ} \mathrm{C}\right.$ water bath to maintain normothermia) through which humidified $8 \%$ oxygen (balance nitrogen) flowed for 45 minutes. Following $\mathrm{H}-\mathrm{I}$, the pups were returned to their cages and remained with their mother. Tail DNA was prepared and utilized for PCR. The normal allele generated a 304 basepair product amplified using an exon 5 forward primer $(0.64 \mu \mathrm{M}$ : 5'-TGATCAGAACCATCATG-3') and an intron 5 reverse primer (0.64 $\mu \mathrm{M}: \quad 5^{\prime}$-GTTGACCAGAGTGGCGTAGG-3'). The mutant allele generated a 507 basepair product which was amplified with a neo/pgk primer $(0.16 \mu \mathrm{M}$ : 5'-CCGCTTCCATTGCTCAGCGG-3') and the same intron 5 reverse primer, which together generate a 507 basepair product. The cycling parameters for the reaction were $1 \mathrm{~min}$ at $94^{\circ} \mathrm{C}, 55^{\circ} \mathrm{C}$, and $72^{\circ} \mathrm{C}$ each for a total of 30-35 cycles (16).

\section{Tissue Preparation}

For histological analyses, either 24 hours or 1 week following $\mathrm{H}-\mathrm{I}$, animals were anesthetized with $150 \mathrm{mg} / \mathrm{kg}$ of pentobarbital intraperitoneally and then perfused through the left ventricle with phosphate buffer saline (PBS) ( $\mathrm{pH}$ 7.4). Brains were removed and fixed overnight at $4^{\circ} \mathrm{C}$ in $4 \%$ paraformaldehyde in $0.1 \mathrm{M}$ phosphate buffer ( $\mathrm{pH}$ 7.4). Brains were then cyroprotected overnight at $4^{\circ} \mathrm{C}$ in a solution of $30 \%$ sucrose in $0.1 \mathrm{M}$ phosphate buffer $(\mathrm{pH} 7.4)$. Brains were frozen in dry ice and $50 \mu \mathrm{m}$ coronal sections were cut on a freezing sliding microtome and then stored in $0.1 \mathrm{M}$ Tris-buffered saline (TBS, $\left.\mathrm{pH} 7.5,4^{\circ} \mathrm{C}\right)$. For cresyl violet staining, every sixth section was mounted on a slide beginning with the corpus callosum and ended at the posterior end of the hippocampus. Tissue was stained with cresyl violet at $\mathrm{pH} 3.6$ for $5 \mathrm{~min}$. The slides where then rinsed and dehydrated in ethanol and coverslipped. Damage resulting from H-I was determined by calculating the amount of surviving tissue in coronal sections. For each brain, four sections containing the hippocampus were assessed corresponding to figures 44, 49, 51, and 55 in a mouse brain atlas (35) and seven sections of the cortex were assessed corresponding to figures $24,31,37,44,49,51$, and 55 . The area of each brain region was then calculated and the percent area loss in the lesioned versus the unlesioned hemisphere was determined. The scorer was blinded to genotype of the animals. For analysis comparing \% tissue loss in bax $+/-$ vs. bax $-/-$ mice, data are presented as mean $+/-$ SEM and were analyzed with a t-test with a significance cut off at $\mathrm{P}<0.05$. For DEVD cleavage assay 24 hours after $\mathrm{H}-\mathrm{I}$, animals were perfused with PBS ( $\mathrm{pH}$ 7.4) and brains were removed. Tissue from the cortex and hippocampus were dissected and frozen in dry ice.

\section{Stereological Analysis}

To further assess the volume of the hippocampus and number of CAI and CA3 neurons in bax $+1-$ and bax $-/-$ mice, we utilized unbiased stereological methods. For assessment of hippocampal volume as well as CAl and CA3 neuron number, ten animals (bax $+/-\mathrm{N}=5$; bax $-/-\mathrm{N}=5)$ at $\mathrm{P} 14,7$ days following H-I at P7, were assessed. The brains were sectioned in the coronal plane and every sixth section from the beginning to the end of the hippocampus (rostral to caudal) was mounted on a slide. The sections were stained with the fluorescent dye 4', 6 diamidino-2-phenylindole (DAPI) stain (1:1000). The hippocampal region of every brain section was identified and traced, and the section thickness was determined with a $100 \mathrm{X}$ lens (N.A. 1.40). From that information, the volume of the hippocampus was determined with the Cavalieri Estimator technique using Stereo Investigator software (MicroBrightField, Inc., Colchester, VT). To determine the number of CAl and CA3 neurons in the hippocampus, the Optical Fractionator technique was utilized. The CAl and CA3 areas of the hippocampus were traced on the same brain sections utilizing a $4 x$ lens with the image projected onto a computer screen. At a higher power (100x lens, 1.4 N.A.), neuronal nuclei 
in the CAl and CA3 region were marked if they fell within a $30 \mu \mathrm{m} \times 30 \mu \mathrm{m}(\mathrm{x}, \mathrm{y})$ counting frame within a $15 \mu \mathrm{m}$ z-depth. A $10 \mu \mathrm{m}$ guard zone was utilized. Sampling distances were set so that $100-400$ neuronal nuclei and 100-300 sites per CAl and CA3 region were sampled. The number of neurons in each hippocampal region was then calculated from the information obtained utilizing the Stereo Investigator software.

\section{DEVD Cleavage Assay}

DEVD-AMC cleavage assay was performed as described $(9,36,37)$. Frozen tissue samples were homogenized in lysis buffer (10 mM HEPES, pH 7.4, $5 \mathrm{mM} \mathrm{MgCl}$, $1 \mathrm{mM}$ DTT, $1 \%$ Triton X-100, $2 \mathrm{~mm}$ EDTA, 2 mM EGTA, 1 mM PMSF, and protease inhibitor cocktail) and centrifuged at $12,000 \mathrm{~g}$ for $10 \mathrm{~min}$ at $4^{\circ} \mathrm{C}$. Ten $\mu \mathrm{l}$ of the lysate was incubated in a 96-well plate with $90 \mu \mathrm{L}$ of assay buffer $(10 \mathrm{mM}$ Hepes, pH 7.4, $42 \mathrm{mM} \mathrm{KCl}, 5 \mathrm{mM} \mathrm{MgCl}{ }_{2}, 1 \mathrm{mM}$ DTT, $10 \%$ sucrose) containing $30 \mu \mathrm{M}$ Ac-DEVD-AMC (Calbiochem, San Diego, CA). The emitted fluorescence was measured every 5 minutes for 30 minutes at room temperature at an excitation wavelength of $360 \mathrm{~nm}$ and an emission wavelength of $460 \mathrm{~nm}$ using a microplate fluorescence reader (Bio-tek Instruments, Winooski, VT). DEVD activity was obtained from the slope of fluorescence against time. Ac-AMC (Calbiochem, San Diego, CA) was used to obtain a standard curve and the enzyme activity was calculated as the pmol AMC/mg/protein/min. Data are presented as mean $+/-$ SEM. Data were analyzed with ANOVA followed by Newman-Keuls multiple comparisons test with significance cut off at $\mathbf{P}<0.05$.

\section{Immunohistochemistry, Immunofluorescence,} and Western Blotting

Fifty-micrometer free floating sections through the forebrain were processed for peroxidase immunohistochemistry using the rabbit polyclonal antibody CMl to activated caspase-3 (1:20,000; gift of Idun, Inc., La Jolla, CA) $(36,38)$, the rabbit polyclonal antibody SK440 to activated caspase-8 (1:3000, gift of K. Kikly, Smith Kline Beacham Pharmaceuticals, King of Prussia, PA (39)), or the anti-cytochrome c antibody (1:500; PharMingen, Inc., San Diego, CA) with the Vectastain ABC Elite kit (Vector Laboratories, Inc., Burlingame, CA) as previously described (36). For quantitation of the density of activated casapse-8-immunoreactive (IR) cells in the CA3 region of $\mathrm{Bax}+/-$ and Bax $-/-$ mice, 4 hippocampal sections corresponding to figures $44,49,51$, and 55 in a mouse brain atlas (35) were assessed. Four fields measuring $0.023 \mathrm{~mm}^{2}$ in the CA3 region were assessed in each section. Caspase-8-IR cells were assessed by an observer blinded to genotype and were counted as positive if there was staining of a clearly distinguishable cell body in which the staining intensity was greater than the level of any of the cells observed in the contralateral $\mathrm{CA} 3$ region as determined by thresholding utilizing image analysis with an Optiphot digital camera (Nikon, Inc., Melville, NY). For double-labeling immunofluorescence experiments for activated caspase-3, a neuronal nuclear marker, and cytochrome c, brain sections were incubated with the following antibodies: CM1 $(1: 5,000)$ along with mouse anti-neuronal nuclei antibody (1:100) (NeuN; Chemicon, Inc., Temecula, CA) or anti-cytochrome c (1:500). Fluorescein isothiocyanate- and indocarbocyanine-labeled secondary antibodies were utilized for fluorescent detection as described (36). For fluorescent double labeling for activated caspase-3 (CMI) and activated caspase-8 (SK440), sections were first blocked with $1 \%$ BSA and $0.2 \%$ dry milk in Tris-buffered saline (TBS) for one hour and then incubated overnight with SK440 (1:5000 dilution). After washing, sections were incubated with fluorescein-conjugated anti-rabbit antibody using TSA-direct tyramide signal amplification kit (NEN Life Science Products, Boston, MA). Sections were then blocked with 3\% goat serum in TBS for one hour, incubated overnight with CMI (1:5,000 dilution), washed, and then incubated with goat anti-rabbit IgG coupled to Alexa 568 (Molecular Probes, Eugene, OR) for one hour. Controls included omission of each primary antibody. Slides were coverslipped with Vectashield mounting media (Vector Laboratories, Burlingame, CA) and examined with a Nikon FXL fluorescence microscope (Nikon, Inc., Melville, NY) as well as a Bio-Rad Confocal microscope for analysis (Bio-Rad, Inc., Hercules, CA). Western blotting with hippocampal lysates was performed as described $(28,36,37)$. Antibody to FAS was obtained from Upstate Biotechnology (Lake Placid, NY) and antibody to pro-caspase-8 was obtained from Pharmingen, Inc. (San Diego, CA). Quantitation of band density on X-ray film following Western blotting was performed as described (40).

\section{Results \\ Endogenous BAX Plays a Role in Tissue Loss Following $H-I$}

We were interested in the role of BAX in the cell death that occurs in an in vivo model of neonatal brain injury due to $\mathrm{H}-\mathrm{I}$. To address this question, we bred bax $+/-$ male mice to bax $-/-$ female mice and on post-natal day $(\mathrm{P}) 7$, littermates which were either $b a x+/-$ or $b a x-/-$ were given an $\mathrm{H}-\mathrm{I}$ insult. P7 mice underwent unilateral (left) carotid artery ligation and were then exposed to $8 \%$ oxygen for 45 minutes. In this model, cell injury is only observed in the hemisphere ipsi- but not contralateral to the ligation. Animals were sacrificed one week following $\mathrm{H}-\mathrm{I}$ at P14 and the amount of brain injury was determined. Area measurements of the hippocampus from sections stained with cresyl violet showed that $b a x-/-$ animals had significantly less (36\% less) tissue loss than bax $+/-$ animals (Fig. 1 and $2 \mathrm{~A}$ ). There was $25.8+/-5.7 \%$ tissue loss 


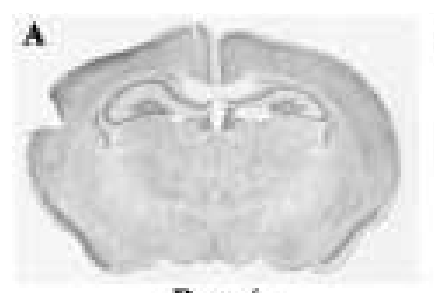

Bax $-1-$

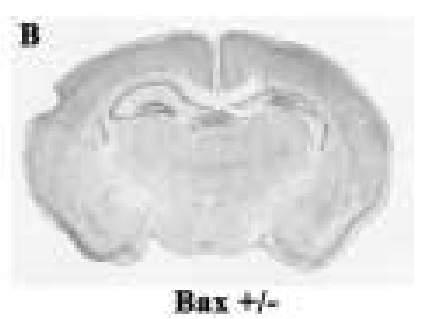

$\mathrm{Bax}+\mathrm{F}=$
Fig. 1. The absence of BAX protects against tissue damage in the neonatal brain following $\mathrm{H}-\mathrm{I}$. An example of brain sections from mice sacrificed at P14, 7 days following H-I at P7, reveals decreased tissue damage in the injured (left) hippocampus of bax $-/-$ mice (A) compared with bax $+/-$ mice (B). For orientation, the lateral cortex was cut on the right side.

observed in bax $-/-$ mice $(\mathrm{N}=22)$, while there was $40.0+/-3.8 \%$ tissue loss observed in bax $+/-$ animals $(\mathrm{N}=31)(\mathrm{P}=0.036)$. It should be noted that we have previously observed virtually identical amounts of hippocampal injury following H-I in P7 C57BL/6 mice which were $b a x+/+$ as compared to results found here with bax $+/-$ mice (ie. $40-45 \%$ tissue loss) $(28,30)$. Of note, H-I in this model is relatively selective for the hippocampus when utilizing the C57BL/6 strain of mice in that following H-I, there is only $10-20 \%$ loss of cortical tissue in the injured hemisphere in this model. When comparing cortical tissue loss in bax $+/-$ versus bax $-/-$ mice, no significant difference was observed (Fig. 2B). Percent tissue loss in bax $-/-$ animals was $14.5+/-4.8 \%$ and in bax $+/-$ animals was $16.0+/-4.0 \%$. Overall, these results demonstrate that the absence of $\mathrm{BAX}$ results in significant but not complete protection against hippocampal tissue loss following neonatal H-I.

Hippocampal Volume Loss Correlates with CA1

Neuronal Loss in $\mathrm{Bax}+/-$ and $\mathrm{Bax}-/-$ Mice Following Neonatal H-I

In this neonatal H-I model, all regions of the hippocampus are damaged and there is not selective vulnerability of only one cellular layer. Coincident with the global neuronal loss in the hippocampus, we previously analyzed CAl neuronal loss in this model and found that hippocampal volume loss correlates well with CAl neuronal loss following H-I injury in the P7 rat (34). While it was not practical to count CAl neurons in the 53 mice analyzed following neonatal H-I, utilizing stereological methods, we determined whether hippocampal volume and percent tissue loss correlates with CAl cell number and percent CAl cell loss respectively in a group of bax $+/-$ and bax $-/-$ following H-I. Bax $+/-(\mathrm{N}=5)$ and bax $-/-(\mathrm{N}=5)$ mice were randomly selected and hippocampal volume CAl cell number were assessed with stereological methods at P14, seven days following unilateral carotid ligation and exposure to $8 \%$ oxygen for 45 minutes. We found that in both bax $+/-$ and bax $-/-$ mice, there was a strong correlation $\left(r^{2}=0.75, p=0.017\right)$ between hippocampal volume and CAl cell number (Fig. 3A). Similarly there was a strong correlation $\left(\mathrm{r}^{2}=0.52, \mathrm{p}=\right.$ $0.019)$ between percent hippocampal volume loss and percent CAl neuron loss (Fig. 3B). There was less CAl cell loss and hippocampal volume loss in the bax $-/-$ versus the bax $+/-$ analyzed in this fashion. In assessing only 5 animals per cohort for stereological analysis, there was not a significant difference in CAl cell number between these groups (Fig. 3C). Taken together, however, with the data in Figure 1 and Figure 2, these results suggest that in addition to having less hippocampal injury, bax $-/-$ mice have less CAl neuronal loss following neonatal H-I.

Caspase-3 Activation is Attenuated But Not Absent in Bax -/- Mice

Following $\mathrm{H}-\mathrm{I}$ in neonatal mice and rats, in addition to necrosis (26), a large amount of neuronal cell death has been shown to have biochemical features of apoptosis $(8,9,27,29,41-43)$. To determine if cells died in the presence and absence of BAX via an apoptotic pathway with caspase activation following H-I, we performed a DEVD-AMC cleavage assay as well as immunostaining with an antibody which is specific
$\mathbf{A}$

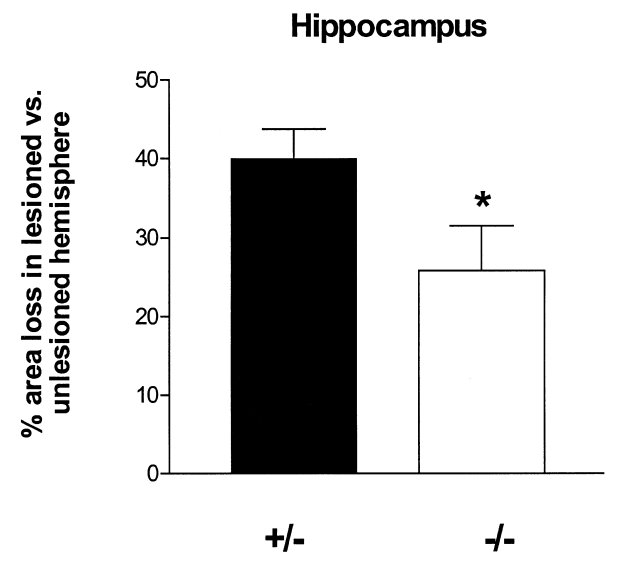

B

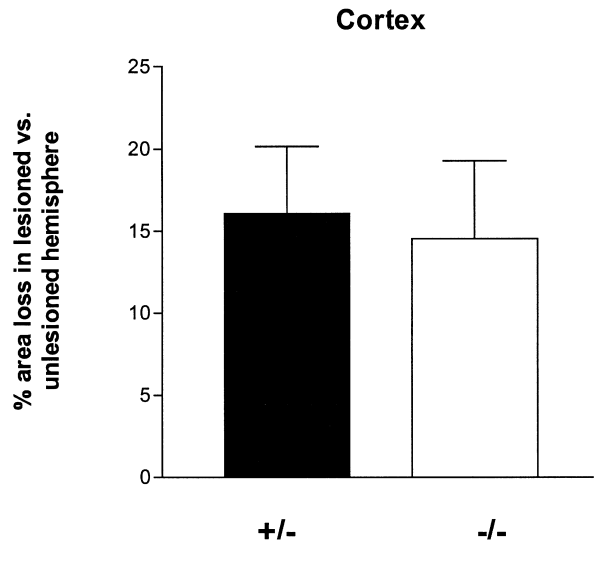

Fig. 2. Bax $-/-$ mice had less hippocampal tissue loss than bax $+/-$ mice after H-I. (A) P14 bax $-/-$ animals $(\mathrm{N}=22), 7$ days after $\mathrm{H}-\mathrm{I}$ at $\mathrm{P} 7$, had $38 \%$ less $(P=0.036)^{*}$ tissue loss in the hippocampus than that observed in $b a x+/-(\mathrm{N}=31)$ animals. (B) $\mathrm{A}$ significant difference was not seen in the amount of tissue loss in the cortex in bax $+/-$ vs. bax $-/-$ mice. 
A

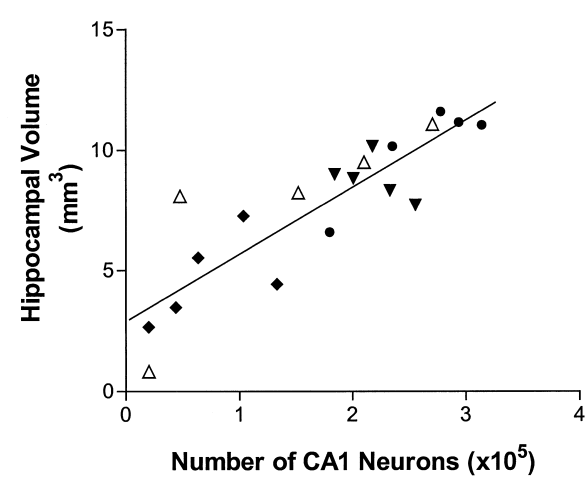

B

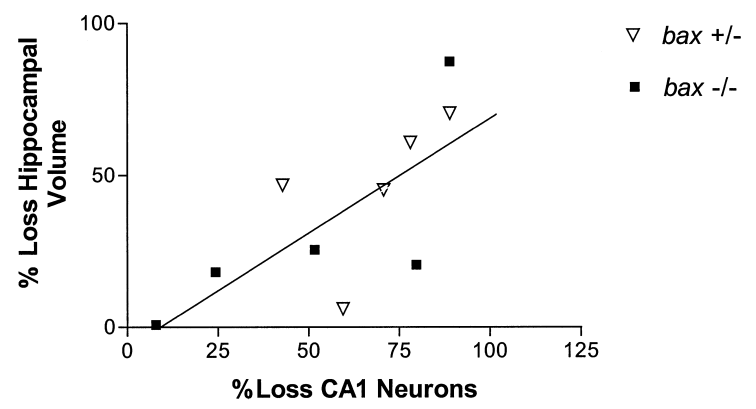

C

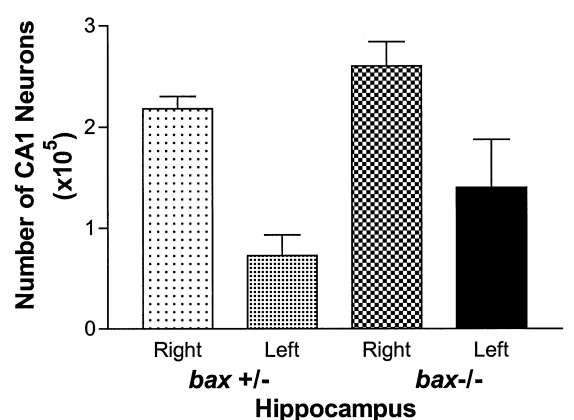

Fig. 3. Hippocampal volume correlates with CAl cell number in the damaged and undamaged hemisphere following neonatal $\mathrm{H}-\mathrm{I}$ in mice. (A) Following unilateral (left) carotid ligation and exposure to hypoxia at P7, the number of CAl neurons and the hippocampal volume in the right and left hippocampus of bax $+/-(\mathrm{N}=5)$ and bax $-/-(\mathrm{N}=5)$ mice were determined. The number of CAl neurons correlated well with the hippocampal volume for bax $+/-$ and bax $-/-$ mice $\left(\mathrm{r}^{2}=0.75, \mathrm{p}=0.017\right)$. (B) The percent loss in CAl neurons correlated well with the percent loss of hippocampal volume $\left(r^{2}=0.52, p=0.019\right)$. (C) There were more CAl neurons in the injured hippocampus of randomly selected bax $-/-$ vs. $b a x+I-$ mice $(\mathrm{N}=5$ per group). The difference was not significant due to the small number of animals in each group assessed in this fashion.

for the activated form of caspase-3, CMI $(36,38)$. For this experiment, $B a x+/-$ mice were bred together and P7 littermates were administered H-I. We examined the brain 24 hours later since our previous experiments have shown a peak of caspase-3-like activation 18-24 hours following H-I $(9,28,44)$. Mice

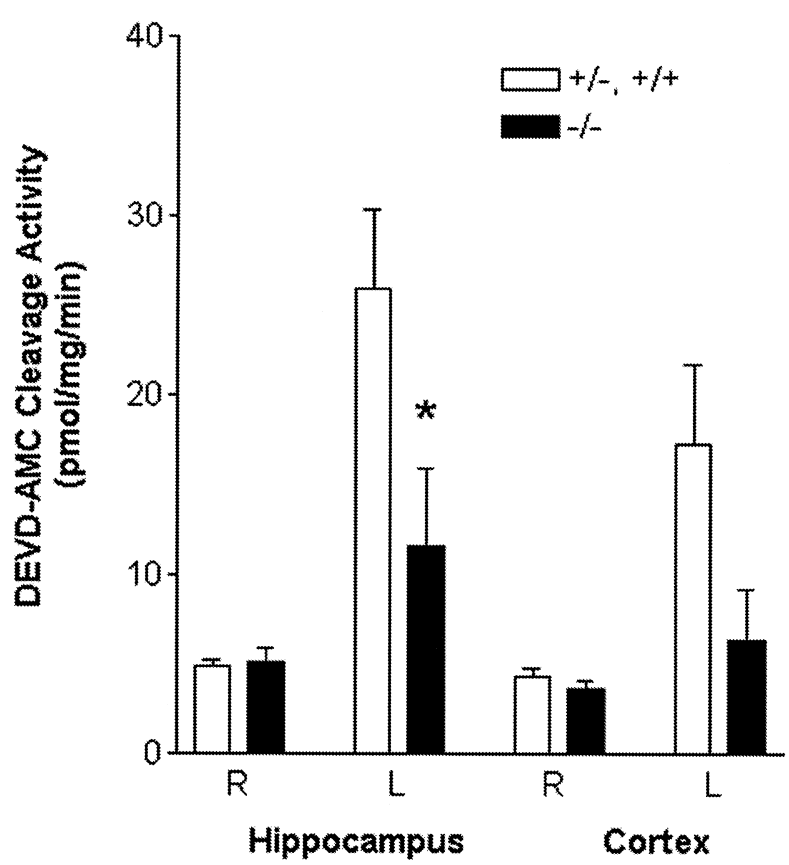

Fig. 4. BAX contributes to but is not required for caspase-3 activation following neonatal H-I. Bax expressing and bax $-/-$ mice showed DEVD-AMC cleavage activity (caspase-3-like activation) in the hippocampus and cortex ipsilateral to the ligation 24 hours following hypoxia. In this experiment, $b a x+/-$ mice were bred together and H-I was performed at P7. DEVD-AMC cleavage activity was assayed with tissue lysates from the hippocampus and cortex contralateral (R) and ipsilateral (L) to the carotid ligation 24 hours following H-I. Data are presented as mean $+/-$ SEM. DEVD-AMC cleavage activity was not statistically different when comparing $b a x+I+$ and $b a x+/-$ mice so data from these 2 groups were pooled. A significant difference was seen when comparing DEVD-AMC cleavage activity in the left hippocampus (ipsilateral to carotid ligation) of the $b a x+/+$ and $+/-$ mice $(\mathrm{N}=36)$ vs. the $b a x-/-$ mice $(\mathrm{N}=11) * \mathrm{P}<0.05$.

were sacrificed and brains were prepared for immunostaining or tissue lysates were prepared for DEVD-AMC cleavage assay. The DEVD-AMC cleavage assay revealed that caspase-3-like activation was significantly attenuated but still present in $b a x-l-$ as compared to bax expressing animals (Fig. 4). Mean DEVD-AMC cleaving activity in the left hippocampus of Bax $-/-$ mice $(\mathrm{N}=11)$ was $11.6+/-4.3$ $\mathrm{pmol} / \mathrm{mg} / \mathrm{min}$ while the mean activity in bax $+/-$ and $+/+$ mice $(\mathrm{N}=36)$ was $26.0+/-4.5 \mathrm{pmol} / \mathrm{mg} / \mathrm{min}$ $(\mathrm{P}=0.04)$. In the left cortex, there was $6.4+/-2.8$ $\mathrm{pmol} / \mathrm{mg} / \mathrm{min}$ of DEVD-AMC cleaving activity in bax $-/-$ mice, while the mean activation in $b a x+/-$ and $+/+$ mice was $17.3+/-4.5 \mathrm{pmol} / \mathrm{mg} / \mathrm{min}(\mathrm{P}>0.05)$. The fact that there was less DEVD-AMC cleavage activity in the cortex of bax $-/-$ vs. bax $+/-$ mice suggests that this assay may be a more sensitive indicator of the effects of BAX than tissue loss.

To further explore the anatomy of caspase- 3 activation, we examined CMl-immunoreactivity (IR) in tissue sections. Bax $+/-$ mice had abundant CMI-IR predominantly in the hippocampus with smaller amounts in the cortex ipsilateral to carotid ligation 


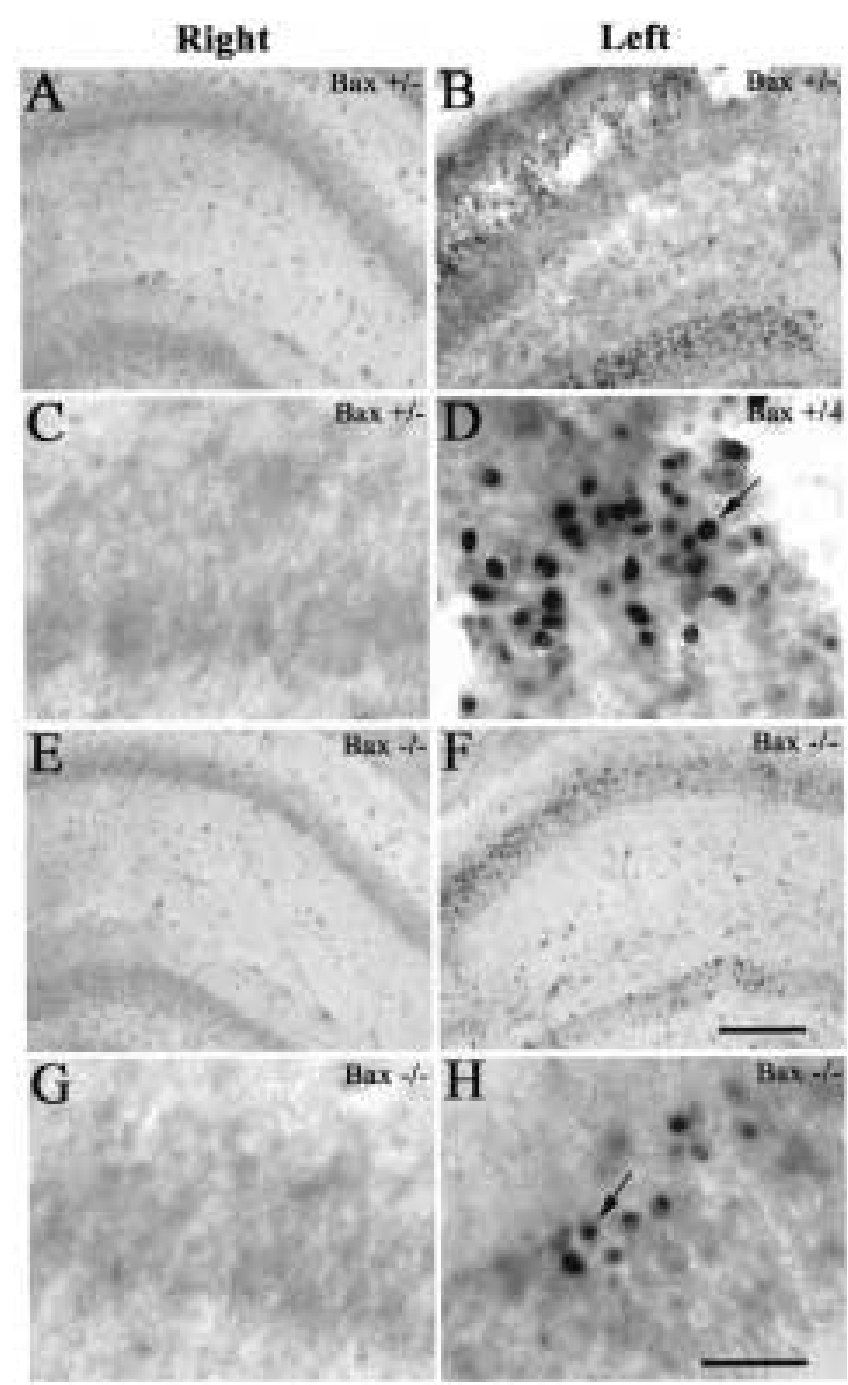

Fig. 5. Activated caspase- 3 is present in bax $+/-$ and $-/-$ neurons following neonatal $\mathbf{H}$-I. Activated caspase-3-IR is observed in the injured (left) hemisphere 24 hours following unilateral (left) carotid artery ligation and exposure to hypoxia for 45 minutes at P7. Activated caspase-3-IR was examined in hippocampal sections at low power $(\mathbf{A}, \mathbf{B}, \mathbf{E}, \mathbf{F})$ and high power $(\mathbf{C}, \mathbf{D}, \mathbf{G}, \mathbf{H})$ in $b a x+/-(\mathbf{A}-\mathbf{D})$ and $b a x-/-(\mathbf{E}-\mathbf{H})$ mice. In-situ caspase- 3 activation is especially evident in neuronal nuclei the hippocampus (arrow), but was also seen in the cortex ipsilateral to the ligation. Qualitatively, there were fewer cells with caspase- 3 activation observed in bax $-/-$ mice (F and $\mathbf{H})$ as compared to bax $+/-$ mice (B and $\mathbf{D})$, confirming results with DEVD-AMC cleavage assay. Scale bar in F for A, B, E, and F, $50 \mu \mathrm{m}$. Scale bar in $\mathrm{H}$ for C, D, G, and H, $20 \mu \mathrm{m}$.

(Fig. 5). While bax $-/-$ mice generally had less CMIIR than bax $+/-$ mice which was consistent with the DEVD-AMC cleavage assay, the absence of BAX did not completely block activation of caspase-3 as visualized by CM1-IR (Fig. 5). In fact, caspase-3 activation as well as cell shrinkage as seen in cresyl violet stained sections appeared qualitatively similar in both bax +/- and bax -I- mice (Fig. 6). As we have previously shown in neonatal rats (36), most of the CM1-positive cells were neurons as determined by

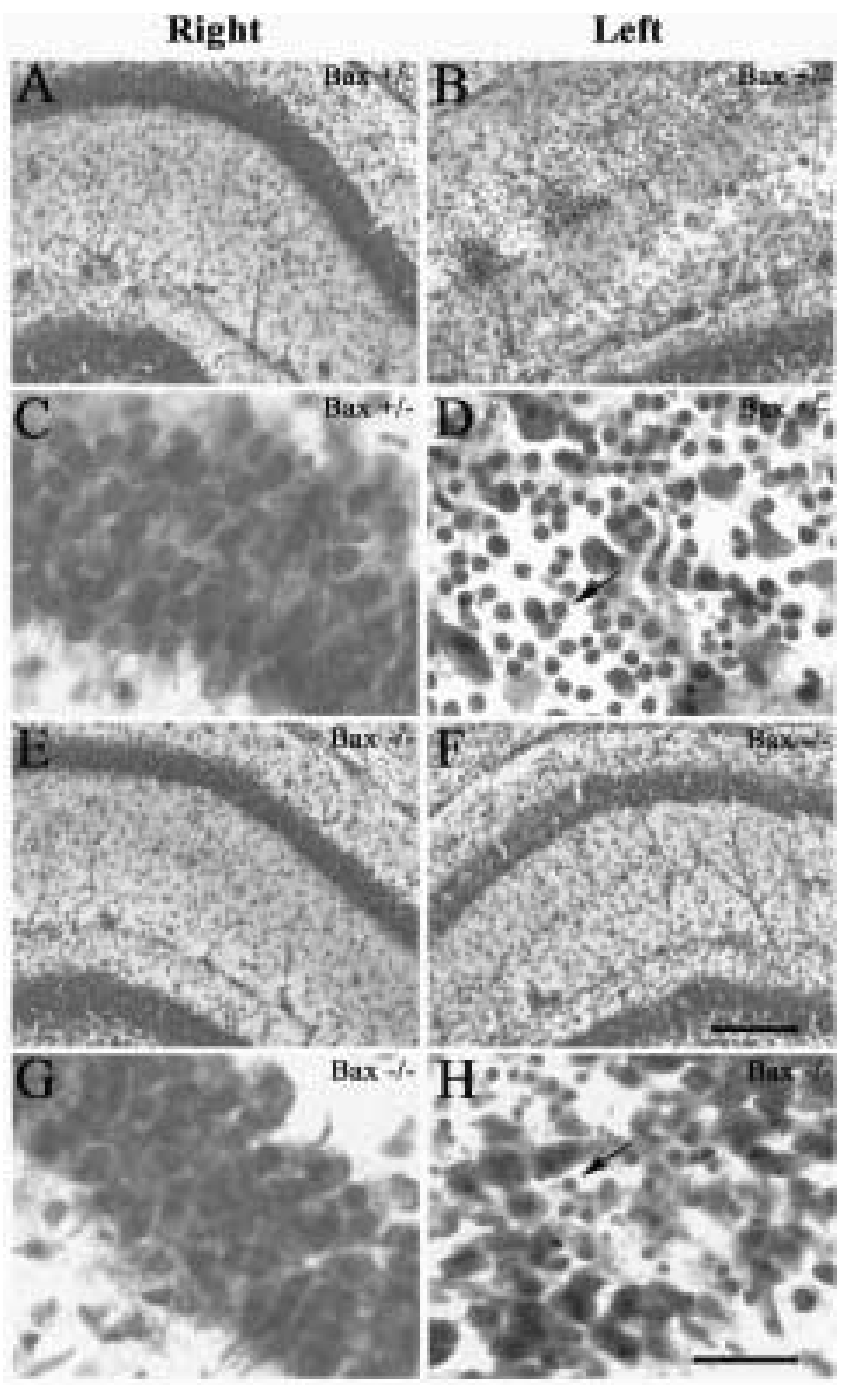

Fig. 6. Evidence of cell shrinkage 24 hours following $\mathrm{H}-\mathrm{I}$ is present in both $B a x+/-$ and $B a x-/-$ mice. Cell shrinkage occurred in the left hemisphere 24 hours following H-I ipsilateral to the carotid ligation. Hippocampal sections were stained with cresyl violet and examined at low power (A, B, E, F) and high power (C, D, G, H) in bax $+/-(\mathbf{A}-\mathbf{D})$ and $b a x-/-$ mice $(\mathrm{E}-\mathrm{H})$. In the CAl region $(\mathrm{C}, \mathrm{D}, \mathrm{G}, \mathrm{H})$, shrunken nuclei with condensed chromatin (arrow) were present in both bax $+/-$ (D) and bax $-/-(\mathrm{H})$ mice but were generally less prominent in bax $-/-$ mice. Scale bar in F for A, B, E, and F, $50 \mu \mathrm{m}$. Scale bar in $\mathrm{H}$ for $\mathrm{C}, \mathrm{D}, \mathrm{G}$, and $\mathrm{H}, 20 \mu \mathrm{m}$.

co-localization with the neuronal marker Neu-N (data not shown). Thus, while H-I induced brain injury was attenuated in bax $-1-$ mice, some apoptotic events including caspase- 3 activation were still observed in the neonatal CNS, even in the absence of BAX.

\section{Caspase-8 Activation is not Blocked} by the Absence of $B A X$

In sympathetic neurons deprived of NGF, BAX translocation to mitochrondria and subsequent cytochrome c release is required for caspase- 3 activation and cell death $(45,46)$. Since there was some 
BAX independent caspase-3 activation following neonatal H-I, we asked whether another pathway could contribute to caspase- 3 activation in the presence and absence of BAX. One mechanism which mammals utilize to direct individual cells to self destruct is via death receptors. Death receptor activation can be directly coupled to activation of caspase- 8 which can then activate downstream effector caspases such as caspase-3, committing cells to apoptosis (47-49). We utilized a recently characterized antibody which is specific for the activated form of caspase-8 (39) and examined bax $+/-$ and bax $-1-$ brains 24 hours after H-I at P7. As with staining for activated caspase-3, a large number of hippocampal neurons had activated caspase-8-IR in the damaged hemisphere with little to no staining in the undamaged hemisphere. While activated caspase- 3 was present in CA1, CA 3 and the dentate gyrus, staining for activated caspase- 8 was predominantly in the CA3 region. Double label immunofluoresence to identify cells with activated caspase-3, activated caspase-8, or both markers was performed twenty four hours following $\mathrm{H}-\mathrm{I}$ in $b a x+/-$ and bax $-1-$ mice at P7. Within the CA3 region, it appeared that most cells which were positive for activated caspase- 8 were also positive for activated caspase- 3 (Fig. 7A-F). On the other hand, there were some cells, particularly in bax $+/-$ mice, which were
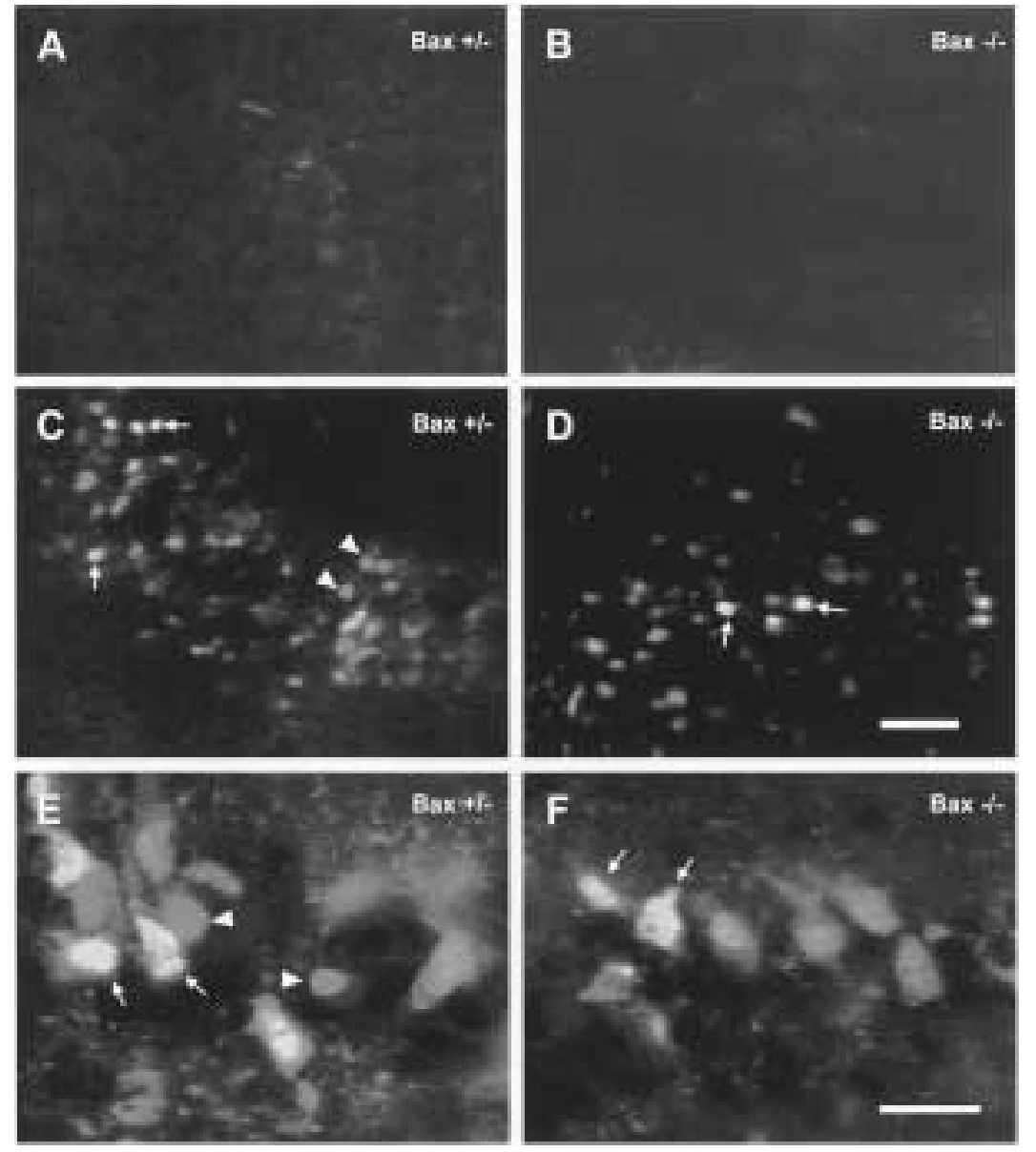

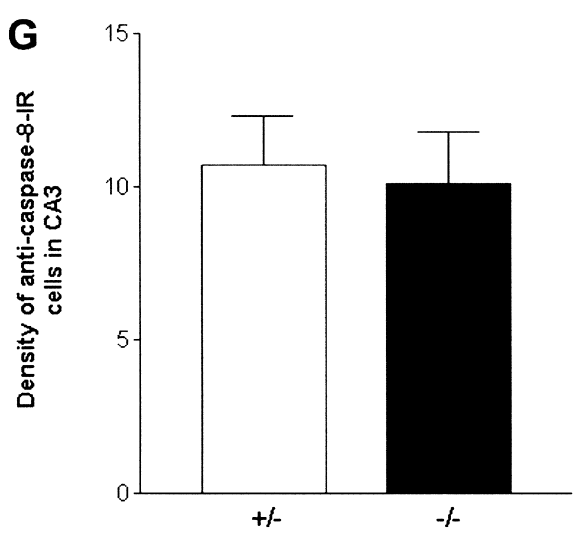

Fig. 7. Caspase-8 activation following neonatal $\mathrm{H}-\mathrm{I}$ is present in both bax $+/-$ and bax $-/-$ mice. P7 mice were subjected to H-I and 24 hours later, sections were labeled with antibodies to activated caspase- 3 and activated caspase- 8 and assessed by double label immunofluorescence and confocal microscopy. There was little staining of cells in the unlesioned right hippocampus in either bax $+/-(\mathbf{A})$ or bax $-/-$ mice (B). In contrast, in the lesioned (left) hippocampus (CA3 shown here), there were cells which labeled with antibodies to activated caspase- 3 (red), activated caspase-8 (green), or were labeled with both antibodies (yellow) (C-F). Most cells that were labeled by antibodies to activated caspase- 8 were also stained by antibodies to activated caspase- 3 (arrows, C-F). There were also cells, particularly in the bax $+1-$ mice, which only labeled with antibodies to activated caspase- 3 (arrowheads, C, E). Scale bar in D equals $50 \mu \mathrm{m}$ for A-D. Scale bar in F equals $10 \mu \mathrm{m}$ for $\mathrm{E}$, F. In G, the density of activated caspase-8-IR cells (per $0.023 \mathrm{~mm}^{2}$ ) in the $\mathrm{CA} 3$ region of the lesioned hippocampus was compared in bax $+I-(\mathrm{n}=5)$ vs. bax $-I-(\mathrm{n}=5)$ mice. The same mice analyzed for CAl neurons in Fig. 3 were utilized in this experiment. There was no significant difference between the groups. The total number of remaining CA3 neurons as well as the \% CA3 cell loss (right-left/right X 100) in both groups was also determined in the uninjured (right) and injured (left) hippocampus of these animals. Number of CA3 neurons (mean $+/-$ SEM): bax $+/-$, right: $98,240+/-11,640 ;$ bax $-/-$, right: $100,800+/-11,900$; bax $+/-$, left: $42,430+/-11,040$; bax $-I-$, left: $42,530+/-$ $15,160)$. \% CA3 cell loss (mean $+/-$ SEM): bax $+/-56.1+/-12.9$; bax $-I-58.4+/-9.7$. 
positive for activated caspase- 3 but contained no detectable activated caspase-8 (Fig. 7C-F). We quantified the density of activated caspase-8-IR cells in the CA3 region of the same bax $+/-$ and $b a x-/-$ mice that we quantified CAl neuronal number in Fig. 3, 24 hours following $\mathrm{H}-\mathrm{I}$ at P7. Interestingly, there was no significant difference in the number of activated caspase- 8 immunopositive cells between the groups (Fig. 7E). Further, we determined the total number of $\mathrm{CA} 3$ neurons in the same group of bax $+/-$ and bax $-/-$ mice. There was an almost identical amount of neuronal loss in the injured CA3 region when comparing the groups (legend, Fig. 7). Taken together, this suggests that while BAX regulates some events leading to caspase- 3 activation following neonatal $\mathrm{H}-\mathrm{I}$ that activation of caspase- 8 in a subset of cells may lead to caspase- 3 activation and cell death in a BAX-independent manner.

While there are several death receptors which could play a role in activation of caspase-8, we qualitatively examined levels of the death receptor FAS as well as pro-caspase- 8 in bax $+/-$ and $-/-$ mice since it was previously shown that FAS levels increase after neonatal H-I in rats $(43,50)$. Twenty-four hours following neonatal $\mathrm{H}-\mathrm{I}$, there was a several fold increase in FAS levels as detected by Western blotting of hippocampal tissue lysates (Fig. 8). Further, there was a decrease in the level of procaspase- 8 consistent with caspase- 8 cleavage and activation. The antibody specific for activated caspase- 8 (SK440) utilized for immunofluorescence was not useful in this assay as it is not sensitive at detecting activated caspase- 8 by Western blotting. There was no quantitative difference between the increased levels of FAS or the decreased levels of pro-caspase-8 between the bax $+/-$ and $-/-$ mice following H-I (Fig. 8). These results further suggest that death receptor induced caspase- 8 activation may contribute to caspase- 3 activation independent of BAX.

\section{Discussion}

The discovery of the BCL-2 family members has led to a better understanding of their role in apoptotic pathways. The role of individual BCL-2 family members in the nervous system in vivo and in specific disease states has not been completely clarified. While BAX is one of the better studied pro-apoptotic BCL-2 family members, its role in apoptotic-like cell death in the brain is just beginning to be defined. Previous studies have demonstrated that antiapoptotic BCL-2 family members are expressed in the brain and that their expression levels can regulate cell death following ischemic injury $(29,51-54)$. In addition, the expression of the pro-apoptotic BCL-2 family member bax is increased following ischemic brain injury $(43,55-57)$. A recent study in an adult $\mathrm{H}-\mathrm{I}$ model utilized an inhibitor of a BAX interacting protein and this resulted in neuroprotection (58). To our knowledge, however, this study is
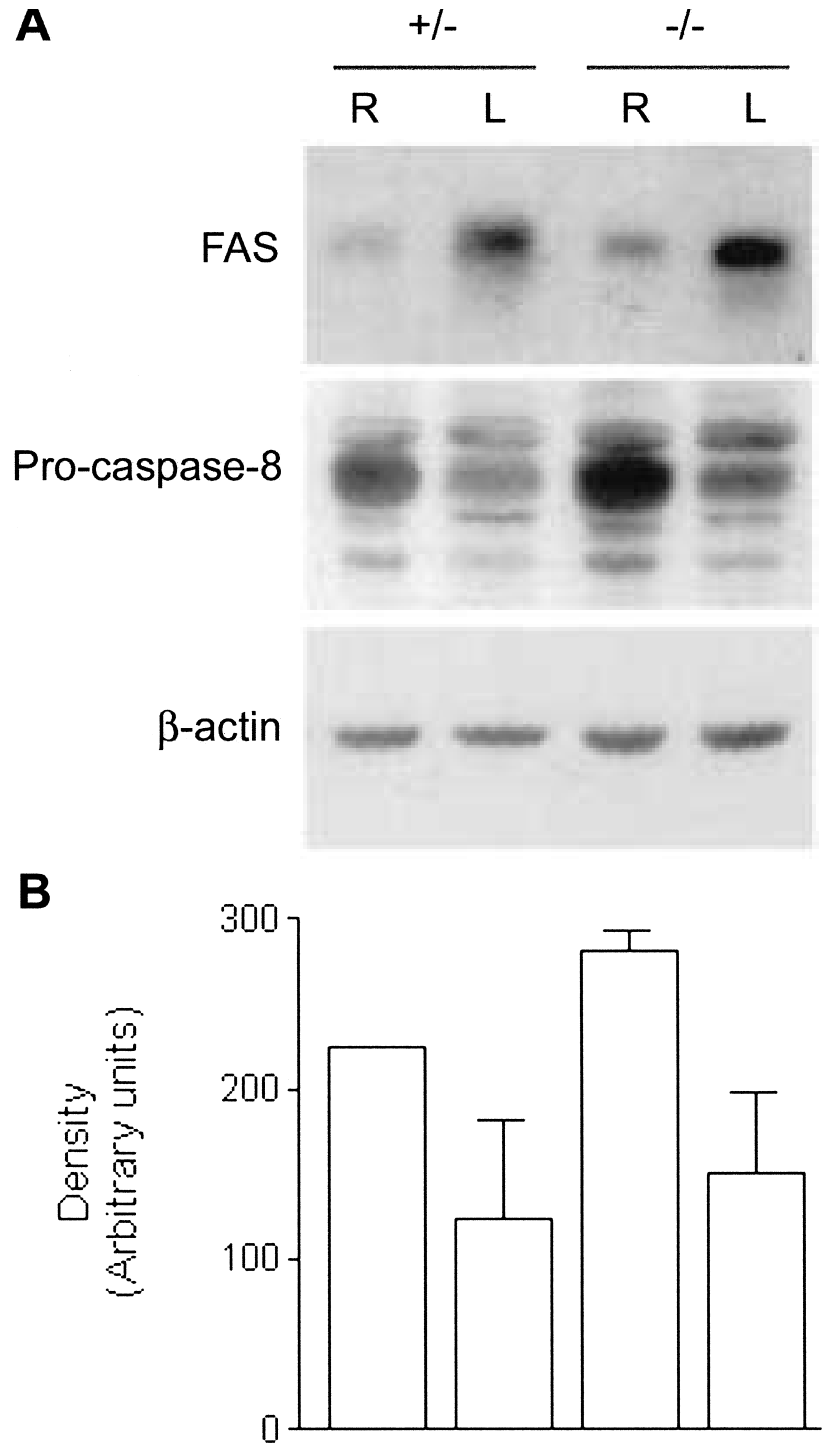

Fig. 8. FAS increases and pro-caspase-8 decreases following neonatal H-I. (A) Twenty four hours following H-I at P7, hippocampal lysates from bax $+/-$, and $-/-$ mice $(30 \mu \mathrm{g}$ protein per lane) from the undamaged-right (R) and damaged-left (L) hemisphere were assessed by SDS-PAGE followed by Western blotting with antibodies to FAS, pro-caspase- 8 and $\beta$-actin. There was a clear increase in FAS $(\sim 45 \mathrm{kDa})$ and a decrease in pro-caspase-8 ( $\sim 57 \mathrm{kDa})$ in all types of mice assessed. (B) The density of the band corresponding to full length caspase- 8 was determined in the right and left hippocampi of groups of bax $+/-$ and bax $-1-$ mice corresponding to the lanes shown above in A. There was no statistical difference in the amount of caspase- 8 24 hours following $\mathrm{H}$-I when comparing the injured (L)

hippocampi between bax $+/-$ to bax $-I-$ mice $(\mathrm{N}=4$ per group).

the first to examine the contribution of endogenous BAX to injury in an in vivo model of neonatal or adult $\mathrm{H}-\mathrm{I}$. We found that the absence of BAX attenuates cell death and caspase-3 activation in vivo following an H-I insult to the neonatal brain. Despite the decrease in the amount of injury, some injury was still observed and the absence of BAX did not completely prevent caspase activation or cytochrome c release. 
The absence of BAX also had no clear effect on the density of cells with caspase-8 activation as assessed in the CA3 region of the hippocampus. Thus, while the absence of BAX can completely prevent neuronal cell death under certain conditions in the nervous system (eg. post-mitotic programmed cell death in the PNS) in which mitochondrial changes leads to apoptosome activation, its role in the apoptotic-like cell death following $\mathrm{H}-\mathrm{I}$ in the developing brain appears to be more complex (see model, Fig. 9).

In this murine model of neonatal $\mathrm{H}-\mathrm{I}$, the absence of BAX resulted in neuroprotection in the hippocampus. The degree of neuroprotection observed in this study was similar to that seen in our previous studies of neonatal H-I in which we used other antiapoptotic strategies. For example, there was 39\% less hippocampal and $61 \%$ less cortical damage following H-I in neonatal transgenic mice overexpressing $B c l-X_{L}$ as compared to age-matched littermate controls (29). In addition, following neonatal H-I in P7 rats, the administration of the pan-caspase inhibitor BAF resulted in approximately $50 \%$ less injury to the hippocampus and cortex (9). Other studies also suggest that caspases including caspase-9 and -3 are not only important in programmed cell death $(59,60)$ but also in ischemia-mediated death following brain injury $(61,62)$. Together, these studies indicate that apoptotic-like pathways are not only involved in a significant percent of brain injury following neonatal H-I but also suggest that a variety of

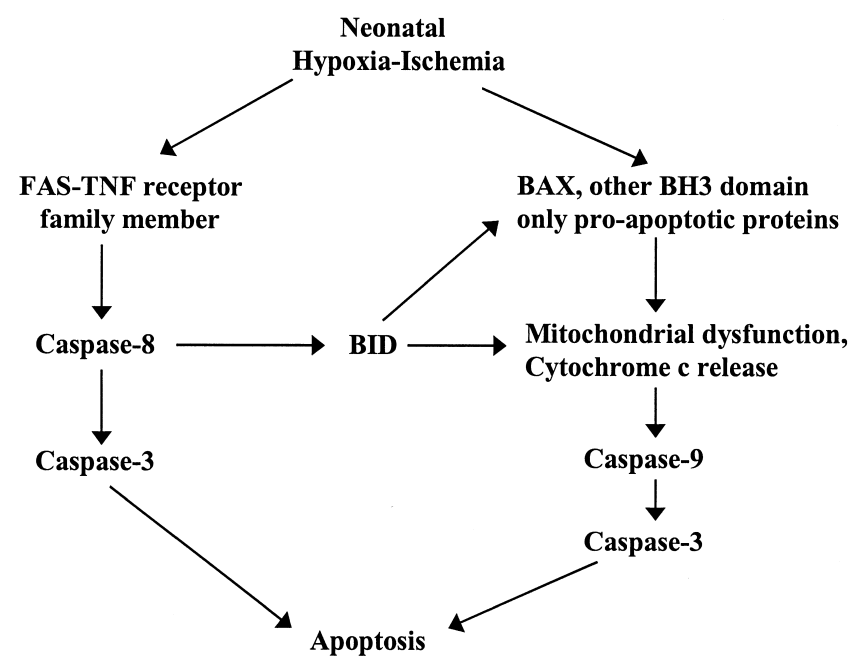

Fig. 9. Model of caspase-dependent cell death which occurs following neonatal hypoxia-ischemia (H-I). BAX likely plays a role in modulating caspase- 3 activation via translocation to the mitochondria, release of cytochrome c, apoptosome formation, and activation of caspase- 9 and -3 . Caspase- 8 activation may contribute to apoptotic-like death following neonatal H-I, as occurs in vitro and other paradigms, via BAX-dependent and independent pathways. How caspase- 8 becomes activated in the neonatal brain has not yet been clarified. It is likely to occur via activation of a death receptor such as FAS or a member of a member of the TNF receptor family. anti-apoptotic strategies and molecules could be targeted for potential drug development.

While our study demonstrates that endogenous $\mathrm{BAX}$ is involved in apoptotic-like death following neonatal H-I, some death with caspase- 3 activation still occurred in the absence of BAX. The amount of protection was similar in this study to that seen following ionizing radiation to the P5 mouse cerebellum where bax $-/-$ mice had an approximately $50 \%$ reduction of apoptosis compared with wild-type mice (20). Further, apoptotic cell death in cerebellar granule cells of Lurcher mice was blocked in bax $-/-$ mice (19). The presence of activated capase3 that we observed in the present study in the absence of BAX suggests that one possibility is that other BAX-like molecules may also be contributing to the cytochrome $\mathrm{c}$ dependent death occurring following neonatal $\mathrm{H}-\mathrm{I}$. There are several proapoptotic $B c l-2$ family members including $B a x, B c l-X_{S}$, Nbk/Bik, Bim, Bad, Bid, Harikari, and Bak. Some of these genes have been shown to be expressed in the brain $(55-57,63,64)$, though their expression and role in the developing brain remains to be characterized. Studies by Han et al. (65) and Zhai et al. (66) show that Bid is expressed in the brain and may be a cytochrome c efflux-inducing factor. It is interesting to note that caspase- 8 is activated in some neurons in an adult stroke model (39) and can cleave BID which can lead to mitochondrial damage, cytochrome c release, and cell death (67-71). This prompted us to look for caspase-8 activation in the neonatal model.

Caspase- 8 was originally identified via proteinprotein interactions and was found to contain two death effector domain-like modules allowing it to interact with FADD $(47,48,72-74)$. FADD is an adaptor protein which directly couples cell surface signaling via death receptors belonging to the TNF receptor gene superfamily to activation of caspase-8, (for reviews see $(75,76)$ ). Upon activation, caspase-8 can lead to activation of many other downstream caspases such as caspase-9 and -3 (47-49). It has been proposed that the amount of caspase- 8 activation may determine whether a mitochondrialdependent pathway is required for amplification of the caspase cascade (69). While BAX-regulated mitochondrial events influence a significant amount of cell death following neonatal $\mathrm{H}-\mathrm{I}$, our data in mice as well as other data from rats $(43,58)$ suggest that caspase-8 may regulate BAX-independent apoptoticlike death and caspase- 3 activation associated with cytochrome c release following H-I (Fig. 9). This could occur via direct caspase- 9 and -3 cleavage by caspase-8. Alternatively, caspase- 8 has been shown to amplify cytochrome $c$ release via cleavage of BID and its translocation to the mitochondria (67-70). There, caspase-8-activated BID can trigger homooligomerization of both $\mathrm{BAX}$ and $\mathrm{BAK}$ resulting in cytochrome c release and apoptosis $(77,78)$. While the absence of BAX may lessen the effect of caspase- 8 following neonatal $\mathrm{H}-\mathrm{I}$, it is possible that the presence 
of BAK or another BH3-domain only homologue still allows for caspase-8 mediated mitochondrial dysfunction. In light of these results, it is interesting to note that Fas, a death receptor linked to caspase- 8 activation, is present in the developing brain and is upregulated following H-I (50). In addition, some apoptosis-inducing agents, such as staurosporine, can result in caspase- 8 activation in cultures of cortical neurons (79). It will be interesting in future experiments to further define the role of death receptor ligands/receptors and caspase- 8 in neonatal $\mathrm{H}-\mathrm{I}$ as well as the role of BID in caspase-8 actions in vivo.

This study shows that the absence of $\mathrm{BAX}$ is protective against apoptotic-like death following neonatal H-I. Our previous studies have shown that molecules such as brain-derived neurotrophic factor (BDNF) can completely block the apoptotic as well as most of the non-apoptotic components of cell death following neonatal H-I $(34,36,37)$. In addition, BDNF can protect against H-I-induced learning abnormalities (23). Important issues that remains regarding anti-apoptotic strategies in general is determining exactly which pathways are involved, the maximum protection that can be achieved, a detailed timecourse of when in relation to injury therapeutic agents can be administered, and whether different agents can be used in combination to achieve even greater neuroprotection. These issues will be important to understand in the setting of both neonatal $\mathrm{H}-\mathrm{I}$ as well as following other injuries to the developing brain.

\section{Acknowledgments}

This work was supported by NIH grant NS35902. The authors thank Eugene Johnson, Mohanish Deshmukh, and Jeff Gidday.

\section{References}

1. Oppenheim RW. (1991) Cell death during the development of the nervous system. Annu. Rev. Neurosci. 14: 453-501.

2. Nijhawan D, Honarpour N, Wang XD. (2000) Apoptosis in neural development and disease. Ann. Rev. Neurosci. 23: 73-87.

3. Ferrer I, Tortosa A, Macaya A, et al. (1994) Evidence of nuclear DNA fragmentation following hypoxia-ischemia in the infant rat brain, and transient forebrain ischemia in the adult gerbil. Brain Path. 4: 115-122.

4. Mehmet H, Yue X, Squier MV, et al. (1994) Increased apoptosis in the cingulate sulcus of newborn piglets following transient hypoxia-ischaemia is related to the degree of high energy phosphate depletion during the insult. Neurosci. Lett. 181: $121-125$.

5. Hill IE, MacManus JP, Rasquinha I, Tuor UI. (1995) DNA fragmentation indicative of apoptosis following unilateral cerebral hypoxia-ischemia in the neonatal rat. Brain Res. 676: 398-403.

6. Sidhu S, Tuor UI, Del Bigio MR. (1997) Nuclear condensation and fragmentation following cerebral hypoxia-ischemia occurs more frequently in immature than older rats. Neurosci. Lett. 223: 129-132.

7. Silverstein FS, Barks JD, Hagan P, Liu XH, Ivacko J, Szaflarski J. (1997a) Cytokines and perinatal brain injury. Neurochem. Int. 30: 375-383.
8. Pulera MR, Adams LM, Liu HT, et al. (1998) Apoptosis in a neonatal rat model of cerebral hypoxia-ischemia. Stroke 29: 2622-2629.

9. Cheng Y, Deshmukh M, D'Costa A, et al. (1998) Caspase inhibitor affords neuroprotection with delayed adminstration in a rat model of neonatal hypoxic-ischemic brain injury. J. Clin. Invest. 101: 1992-1999.

10. Taylor DL, Edwards AD, Mehmet H. (1999) Oxidative metabolism, apoptosis and perinatal brain injury. Brain Path. 9: 93-117.

11. Holtzman DM, Deshmukh M. (1997) Caspases: A treatment target for neurodegenerative diseases? Nature Med. 3 954-955.

12. Chan SL, Mattson MP. (1999) Caspase and calpain substrates: roles in synaptic plasticity and cell death. J. Neurosci. Res. 58: 167-190.

13. Gross A, McDonnell JM, Korsmeyer SJ. (1999) Blc-2 family members and the mitochondria in apoptosis. Genes and Development 13: 1899-1911.

14. Oltvai ZN, Milliman CL, Korsmeyer SJ. (1993) Bcl-2 heterodimerizes in vivo with a conserved homolog bax, that accelerates programed cell death. Cell 74: 609-619.

15. Sedlak TW, Oltvai ZN, Yang E, et al. (1995) Multiple Bcl-2 family members demonstrate selective dimerizations with Bax. Proc. Natl. Acad. Sci. USA 92: 7834-7838.

16. Deckwerth TL, Elliott JL, Knudson CM, Johnson EMJ, Snider WD, Korsmeyer SJ. (1996) BAX is required for neuronal death after trophic deprivation and during development. Neuron 17: 1-20.

17. Miller TM, Moulder KL, Knudson CM, et al. (1997) Bax deletion further orders the cell death pathway in cerebellar granule cells and suggests a caspase-independent pathway to cell death. J. Cell Biol. 139: 205-217.

18. White FA, Keller-Peck CR, Knudson CM, Korsmeyer SJ, Snider WD. (1998) Widespread elimination of naturally occurring neuronal death in Bax-deficient mice. J. Neurosci. 18: $1428-1439$.

19. Doughty ML, De Jager PL, Korsmeyer SJ, Heintz N. (2000) Neurodegeneration in Lurcher mice occurs via multiple cell death pathways. J. Neurosci. 20: 3687-3694.

20. Chong MJ, Murray MR, Gosink EC, et al. (2000) Atm and Bax cooperate in ionizing radiation-induced apoptosis in the central nervous system. Proc. Natl. Acad. Sci. USA 97: 889-894.

21. Vanucci RC. (1990) Experimental biology of cerebral hypoxia-ischemia: relation to perinatal brain damage. Pediatr. Res. 27: 317-326.

22. Volpe JJ (1995) Neurology of the newborn (W. B. Saunders, Philadelphia).

23. Almli CR, Levy TJ, Han BH, Shah AR, Gidday JM, Holtzman DM. (2000) BDNF protects against spatial memory deficits following neonatal hypoxia-ischemia. Exp. Neurol. 166: 99-114.

24. Levine S. (1960) Anoxic-ischemic encephalopathy in rats. Am. J. Pathol. 36: 1-17.

25. Rice JE, Vannucci RC, Brierley JB. (1981) The influence of immaturity on hypoxic-ischemic brain damage in the rat. Ann. Neurol. 9: 131-141.

26. Ikonomidou C, Mosinger JL, Salles KS, Labruyere J, Olney JW. (1989) Sensitivity of the developing rat brain to hypobaric/ ischemic damage parallels sensitivity to $\mathrm{N}$-methyl-aspartate neurotoxicity. J. Neurosci. 9: 2809-2818.

27. Nakajima W, Ishida A, Lange MS, et al. (2000) Apoptosis has a prolonged role in the neurodegeneration after hypoxic ischemia in the newborn rat. $J$ Neurosci 20: 7994-8004.

28. Han BH, DeMattos RB, Dugan LL, et al. (2001) Clusterin contributes to caspase-3-independent brain injury following neonatal hypoxia-ischemia. Nat Med 7: 338-343.

29. Parsadanian AS, Cheng Y, Keller-Peck CR, Holtzman DM, Snider WD. (1998) Bcl-XL is an anti-apoptotic regulator for postnatal CNS neurons. J. Neurosci. 18: 1009-1019.

30. Lendon CL, Han BH, Salimi K, et al. (2000) No effect of apolipoprotein $\mathrm{E}$ on neuronal cell death due to excitotoxic and apoptotic agents in vitro and neonatal hypoxic ischaemia in vivo. Eur. J. Neurosci. 12: 2235-2242. 
31. Ferriero DM, Holtzman DM, Black SM, Sheldon RA. (1996) Mice without neuronal nitric oxide synthase have less injury after perinatal hypoxia-ischemia. Neurobiol. Dis. 3: 64-71.

32. Knudson CM, Tung KSK, Tourtellotte WG, Brown GAJ, Korsmeyer SJ. (1995) Bax-deficient mice with lymphoid hyperplasia and male germ cell death. Science 270: 96-98.

33. Johnston MV. (1983) Neurotransmitter alterations in a model of perinatal hypoxic-ischemic brain injury. Ann. Neurol. 13: 511-518.

34. Cheng Y, Gidday JM, Yan Q, Shah AR, Holtzman DM. (1997) Marked age-dependent neuroprotection by BDNF against neonatal hypoxic-ischemic brain injury. Ann. Neurol. 41: 521-529.

35. Franklin KBJ, Paxinos G (1997) The Mouse Brain in Stereotaxic Coordinates (Academic Press, Inc., San Diego).

36. Han BH, D'Costa A, Back SA, et al. (2000) BDNF blocks caspase-3 activation in neonatal hypoxia-ischemia. Neurobiol. Dis. 7: 38-53.

37. Han BH, Holtzman DM. (2000) BDNF protects the neonatal brain from hypoxic-ischemic injury in vivo via the ERK pathway. J. Neurosci. 20: 5775-5781.

38. Srinivasan A, Roth KA, Sayers RO, et al. (1998) In Situ immunodetection of activated caspase-3 in apoptotic neurons in the developing nervous system. Cell Death $\theta$ Diff. 5: 1004-1016.

39. Velier JJ, Ellison JA, Kikly KK, Spera PA, Barone FC, Feuerstein GZ. (1999) Caspase-8 and caspase-3 are expressed by different populations of cortical neurons undergoing delayed cell death after focal stroke in the rat. J. Neurosci. 19: 5932-5941.

40. Holtzman DM, Bayney RM, Li Y, et al. (1992) Dysregulation of gene expression in mouse trisomy 16, an animal model of Down syndrome. EMBO J. 11: 619-627.

41. Selznick LA, Holtzman DM, Han BH, et al. (1999) In Situ Immunodetection of neuronal caspase- 3 activation in Alzheimer disease. J. Neuropath. Exp. Neurol. 58: 1020-1026.

42. Northington FJ, Ferriero DM, Graham EM, Traystman RJ, Martin LJ. (2001) Early neurodegeneration after hypoxiaischemia in neonatal rat is necrosis while delayed neuronal death is apoptotis. Neurobiol. Dis. 8: 207-219.

43. Northington FJ, Ferriero DM, Flock DL, Martin LJ. (2001) Delayed neurodegeneration in neonatal rat thalamus after hypoxia-ischemia is apoptosis. J. Neurosci. 21: 1931-1938.

44. Han BH, D'Costa A, Back SA, et al. (2000) BDNF blocks caspase-3 activation in neonatal hypoxia-ischemia. Neurobiol. Dis. 7: $38-53$.

45. Deshmukh M, Johnson EM. (1998) Evidence of a novel event during neuronal death-development of competence-to-die in response to cytoplasmic cytochrome C. Neuron 21: 695-705.

46. Putcha GV, Deshmukh M, Johnson J, E. M. (1999) Bax translocation is a critical event in neuronal apoptosis: regulation by neuroprotectants, bcl-2, and caspases. J. Neurosci. 19: 7476-7485.

47. Srinivasula SM, Ahmad M, Fernadnes-Alnemri T, Litwack G, Alnemri ES. (1996) Molecular ordering of the Fas-apoptotic pathway: The fas/APO-1 protease Mch5 is a CrmAinhibitable protease that activates multiple Ced-3/ICE-like cysteine proteases. Proc. Natl. Acad. Sci. USA 93: 14486-14491.

48. Muzio M, Chinnaiyan AM, Kischkel FC, et al. (1996) FLICE, a novel FADD-homologous ICE/CED-3-like protease, is recruited to the CD95 (Fas-APO-1) death-inducing signaling complex. Cell 85: 817-827.

49. Stennicke HR, Jurgensmeier JM, Shin H, et al. (1998) Procaspase-3 is a major physiological target of caspase-8. J. Biol. Chem. 273: 27084-27090.

50. Felderhoff-Mueser U, Taylor DL, Greenwood K, et al. (2000) Fas/CD95/APO-1 can function as a death receptor for neuronal cells in vitro and in vivo and is upregulated following cerebral hypoxic-ischemic injury to the developing rat brain. Brain Pathol. 10: 17-29.

51. Martinou J-C, Dubois-Dauphin M, Staple JK, et al. (1994) Overexpression of bcl-2 in transgenic mice protects neurons from naturally occurring cell death and experimental ischemia. Neuron 13: 1017-1030.
52. Chen J, Graham SH, Nakayama M, et al. (1997) Apoptosis repressor genes $\mathrm{Bcl}-2$ and $\mathrm{Bcl}-\mathrm{x}$-long are expressed in the rat brain following global ischemia. J. Cerebral Blood Flow Metab. 17: 2-10.

53. Minami M, Jin KL, Li W, Nagayama T, Henshall DC, Simon RP. (2000) Bcl-w expression is increased in brain regions affected by focal cerebral ischemia in the rat. Neurosci. Lett. 279: 193-195.

54. Yan C, Chen J, Chen D, et al. (2000) Overexpression of the cell death suppressor Bcl-w in ischemic brain: implications for a neuroprotective role via the mitochondrial pathway. J. Cerebral Blood Flow Metab. 20: 620-630.

55. Krajewski S, Mai JK, Krajewska M, Sikorska M, Mossakowski MJ, Reed JC. (1995) Upregulation of Bax protein levels in neurons following cerebral ischemia. J. Neurosci. 15: 63646376.

56. Hara A, Iwai T, Niwa M, et al. (1996) Immunohistochemical detection of Bax and Bcl-2 proteins in gerbil hippocampus following transient forebrain ischemia. Brain Res. 711: 249-253.

57. MacGibbon GA, Lawlor PA, Sirimanne ES, et al. (1997) Bax expression in mammalian neurons undergoing apoptosis, and in Alzheimer's disease hippocampus. Brain Res. 750: 223-234.

58. Cao G, Minami M, Pei W, et al. (2001) Intracellular Bax translocation after transient cerebral ischemia: Implications for a role of the mitochondrial apoptotic signaling pathway in ischemic neuronal death. J. Cereb. Blood Flow $\theta$ Metab. 21: 321-333.

59. Kuida K, Zheng TS, Na SQ, et al. (1996) Decreased apoptosis in the brain and premature lethality in CPP32-deficient mice. Nature 384: 368-372.

60. Hakem R, Hakem A, Duncan GS, et al. (1998) Differential requirement fo caspase 9 in apoptotic pathways in vivo. Cell 94: 339-352.

61. Hara H, Firedlander RM, Gagliardini V, et al. (1997) Inhibition of interleukin $1 \beta$ converting enzyme family proteases reduces ischemic and excitotoxic neuronal damage. Proc. Natl. Acad. Sci. USA 94: 2007-2012.

62. Chen J, Nagayama T, Jin K, et al. (1998) Induction of caspase3-like protease may mediate delayed neuronal death in the hippocampus after transient cerebral ischemia. J. Neurosci. 18: 4914-4928.

63. Rickman DW, Nacke RE, Rickman CB. (1999) Characterization of the cell death promoter, Bad, in the developing rat retina and forebrain. Brain Res. 115: 41-47.

64. Shimohama S, Fujimoto S, Sumida Y, Tanino H. (1998) Differential Expression of rat brain Bcl-2 family proteins in development and aging. Biochem. Biophys. Res. Comm. 252: 92-96.

65. Han Z, Bhalla K, Pantazis P, Hendreickson EA, Wyche JH. (1999) Cif (cytochrome c effluxing-inducing factor) activity is regulates by Bcl-2 and caspases and correlates with the activation of Bid. Mol. Cell. Biol. 19: 1381-1389.

66. Zhai D, Huang X, Han X, Yang F. (2000) Characterization of Bid-induced cytochrome c release from mitochondria and liposomes. FEBS Lett 472: 293-296.

67. Luo X, Budihardjo I, Zou H, Slaughter C, Wang XD. (1998) BID, a BCL2 interacting protein, mediates cytochrome c release from mitochondria in response to activation of cell surface death receptors. Cell 94: 481-490.

68. Li HL, Zhu H, Xu CJ, Yuan JY. (1998) Cleavage of BID by caspase- 8 mediates the mitochondrial damage in the FAS pathway of apoptosis. Cell 94: 491-501.

69. Kuwana T, Smith JJ, Muzio M, Dixit, V., Newmeyer DD, Kornbluth S. (1998) Apoptosis induction by caspase-8 is amplified through the mitochondrial release of cytochrome c. J. Biol. Chem. 273: 16589-16594.

70. Gross A, Yin XM, Wang K, et al. (1999) Caspase cleaved BID targets mitochondria and is required for cytochrome c release, while BCL-X-L prevents this release but not tumor necrosis factor-R1/Fas death. J. Biol. Chem. 274: 1156-1163.

71. Yin XM, Wang K, Gross A, et al. (1999) Bid-deficient mice are resistant to Fas-induced hepatocellular apoptosis. Nature 400: 886-891. 
72. Boldin MP, Goncharov TM, Goltsev YV, Wallach D. (1996) Involvement of MACH, a novel MORTI/FADD-interacting protease, in Fas/APO-1- and TNF receptor-induced cell death. Cell 85: 803-815.

73. Medema JP, Scaffidi C, Kischkel FC, et al. (1997) FLICE is activated by association with the CD95 death-inducing signaling complex (DISC). EMBO J. 16: 2794-2804.

74. Bertin J, Armstrong RC, Ottilie S, et al. (1997) Death effector domain-containing herpesvirus and poxvirus proteins inhibit both Fas- and TNFR1-induced apoptosis. Proc. Natl. Acad. Sci. USA 94: 1172-1176.

75. Ashkenazi A, Dixit VM. (1998) Death receptors: signaling and modulation. Science 281: 1305-1308.
76. Budihardjo I, Oliver H, Lutter M, Luo X, Wang XD. (1999) Biochemical pathways of caspase activation during apoptosis. Ann. Rev. Cell Devel. Biol. 15: 269-290.

77. Ruffolo SC, Breckenridge DG, Nguyen M, et al. (2000) BIDdependent and BID-independent pathways for BAX insertion into mitochondria. Cell Death $\theta$ Different. 7: 1101-1108.

78. Wei MC, Zong WX, Cheng EH, et al. (2001) Proapoptotic BAX and BAK: a requisite gateway to mitochondrial dysfunction and death. Science 292: 727-730.

79. Budd SL, Tenneti L, Lishnak T, Lipton SA. (2000) Mitochondrial and extramitochondrial apoptotic signaling pathways in cerebrocortical neurons. Proc. Natl. Acad. Sci. USA 97: 61616166. 